\title{
Papillary carcinoma thyroid - A 11 year epidemiological study with histopathological correlation in a tertiary care centre in South Malabar Region in Kerala, India
}

\author{
Ponniah $\mathrm{A}^{1}$, Ilias $\mathrm{LM}^{1}$, Vijayan $\mathrm{P}^{1}$, Mohammed BA ${ }^{1}$, Deeshma $\mathrm{T}^{2}$, Nalakath \\ $\mathrm{AS}^{1}$, Saleem $\mathrm{S}^{1}$, Umasankar $\mathrm{P}^{1}$, Hamza $\mathrm{HK}^{1}$, Ramakrishnan $\mathrm{J}^{1}$ \\ ${ }^{I}$ Department of Pathology, MES Medical College, Perinthalmanna, Kerala, India \\ ${ }^{2}$ Department of Pathology, Malabar Medical College, Kozhikode, Kerala, India
}

\section{Keywords:}

Papillary carcinoma thyroid.

\begin{abstract}
Background: Thyroid cancer is the commonest endocrine malignancy. Based on recent data, thyroid cancer is the fifth most common cancer in women. To our knowledge the present study is the first of its kind, correlating epidemiological and histomorphological data so as to assess the major cause hypothesis for thyroid cancers, focusing more on papillary carcinoma and its variants, comparing it with each other and with other thyroid carcinomas and also correlating with gender, life style and religion.
\end{abstract}

Materials and Methods: This study was conducted in the Department of Pathology, MES Medical College, Perinthalmanna, Kerala, India, from January 2004 to June 2015.Two thousand and fifty thyroidectomy cases were studied.

RESULTS: Out of the total 2050 cases, thyroid cancers constituted 295 (14.39\%); of which 10.1\% (208 cases) were papillary carcinoma thyroid (PCT) and its variants; 165 cases were seen in females $(79.33 \%)$ and the incidence in males were only $20.68 \%$ (43 cases). The commonest variant encountered was classical papillary carcinoma (113 cases, 54.32\%).

CONCLUSION: Our study of papillary thyroid carcinomas in South Malabar region, Kerala, India shows that there is a high incidence of thyroid carcinomas in our locality and this could be attributed to various factors like high intake of iodine along the coastal region, excessive salt iodization, increased consumption of processed food and fish, influence of female sex hormones, increased incidence of autoimmune thyroiditis and exposure to radiation. Our study also showed an increased incidence of PCT in females and among men and women of Islamic faith.

\section{INTRODUCTION}

Thyroid gland is one of the most responsive and largest

\section{Correspondence:}

Dr. Anupama Ponniah, MD

Department of Pathology, MES Medical College,

Perinthalmanna, Kerala, India.

Email:anupamasanjaynair@gmail.com endocrine organs in the body and contains the maximum store of hormones. This gland plays an important role in the metabolic process through secretion of its hormones and responds to many stimuli. It is in a constant state of adaptation .During puberty, pregnancy or and any physiologic stress, thyroid gland increases in size and becomes more active. ${ }^{1}$

Thyroid diseases are very common in the general population, 
Table 1: Total thyroid carcinomas

\begin{tabular}{|c|c|c|c|c|c|c|c|c|}
\hline \multirow{2}{*}{$\begin{array}{c}\text { Religion } \\
\text { Gender }\end{array}$} & \multicolumn{2}{|c|}{ Hindu } & \multicolumn{2}{|c|}{ Christian } & \multicolumn{2}{|c|}{ Muslim } & \multirow[t]{2}{*}{ Male } & \multirow[t]{2}{*}{ Female } \\
\hline & Male & Female & Male & Female & Male & Female & & \\
\hline Total & 13 & 41 & 2 & 9 & 42 & 188 & 57 & 238 \\
\hline Grand Total & \multicolumn{2}{|c|}{$54 / 295(18.3 \%)$} & \multicolumn{2}{|c|}{$11 / 295(3.73 \%)$} & \multicolumn{2}{|c|}{$230 / 295(77.97 \%)$} & \multicolumn{2}{|c|}{$295(100 \%)$} \\
\hline Percentage & $24.7 \%$ & $75.92 \%$ & $18.18 \%$ & $81.81 \%$ & $18.26 \%$ & $81.73 \%$ & $19.32 \%$ & $80.67 \%$ \\
\hline
\end{tabular}

especially in women and elderly and is a common cause of endocrine referrals. ${ }^{2}$

Thyroid malignancy is the commonest endocrine malignancy which accounts for about $90 \%$ of head and neck cancers. Incidence of thyroid neoplasms has increased about three fold in the past three decades and some of the causes for this increasing incidence include diagnostic or iatrogenic radiation exposure, change in body-mass index, dietary iodine content, menstrual cycle, pregnancy, fertility drugs, diet, environment and life style. Based on recent data, thyroid cancer is the fifth most common cancer in women. ${ }^{3}$

Most common type of thyroid malignancy is papillary carcinoma which constitutes about $70 \%-80 \%$ of all thyroid cancers. It occurs most frequently in women and presents in the 20-55 years age group., ${ }^{4,5}$ Papillary carcinoma thyroid (PCT) are discovered on routine examination as asymptomatic thyroid nodule that presents as a neck mass. ${ }^{6}$

In a survey conducted by the National Cancer Registry Program, thyroid cancers featured among the top five; Thiruvananthapuram, the capital of Kerala state, India had the highest relative frequency of cases enrolled in the hospital registry. $1.99 \%$ of cases were seen in males and $5.71 \%$ in females. ${ }^{6}$ The reason for this high frequency of thyroid cancers or the reason for this high prevalence of endemic goiter despite extensive salt iodization are still not fully understood. Thyroid cancer incidence by gender, age and racial/ethnic groups is striking with rates being particularly high in women in younger age group. ${ }^{78}$

The present undertaking is a 11 year study in which we have attempted to highlight the various morphological patterns in papillary thyroid cancers and tried to assess its incidence with respect to gender, age and religious groups pertaining to South Malabar region in Kerala, India.

The aims of the study are as follows:

1: To assess the load of thyroid malignancies in South Malabar region, Kerala.

2: To specifically focus on the load of papillary thyroid carcinomas among these thyroid malignancies in this region.

3: To assess the correlation, if any, between age, gender, religion and dietary habits of the study population with papillary thyroid carcinoma.

\section{MATERIALS AND METHODS}

This retrospective and prospective study was done in the Department of Pathology, MES Medical College, Perinthalmanna, which is a tertiary referral hospital in South Malabar region in Kerala, India, from January 2004 to June 2015. Prior to the study, permission was obtained from Institutional Ethical Committee. Consent form was signed from the concerned individual in prospective study. Two thousand and fifty thyroidectomy cases were studied. The age, gender, ethnicity and dietary habits of all the cases were taken into consideration. All the lesions were classified according to the latest WHO classification of Tumors of Endocrine organs, 20049. In the retrospective cases, the preserved slides were restained with Haematoxylin and Eosin (H\&E) stains, reviewed and reclassified. Repeat deeper sections were taken from the respective blocks wherever necessary. In the prospective cases, requisite number of bits was taken from appropriate areas during grossing; sections were stained with routine H\&E and studied.

\section{RESULTS}

The total number of thyroid cases studied in the last 11 years were 2050, out of which malignancy was seen in 295 cases (14.39\%); among this, $10.1 \%$ was Papillary carcinoma thyroid (208 cases).

In our 11 year study we obtained a total of 2050 cases; 295 cases $(14.4 \%)$ were thyroid malignancies and the incidence of malignancies in females (11.6\%) were much higher when compared to males $(2.8 \%)$ (Table 1$)$.

Out of the total thyroid malignancies (295 cases), 208 cases $(10.15 \%)$ were papillary carcinoma and its variants. So we can infer from this that PCT is the most commonest malignancy to affect the thyroid gland.

Out of the total 208 cases of PCT; 165 were seen in females (79.33\%); the incidence in males were only $20.68 \%$ (43 cases), with male to female ratio being 1:4.

Out of 208 cases of PCT, 113 cases (54.32\%) were classical papillary carcinoma, follicular variant of papillary 
Table 2: Comparison of Religion and Gender Distribution Of Papillary Carcinoma Variants $(\mathrm{n}=\mathbf{2 0 8})$

\begin{tabular}{|c|c|c|c|c|c|c|c|c|}
\hline \multicolumn{9}{|c|}{ Classical Papillary Carcinoma (fig.1) } \\
\hline \multirow{2}{*}{$\begin{array}{c}\text { Religion } \\
\text { Gender }\end{array}$} & \multicolumn{2}{|c|}{ Hindu } & \multicolumn{2}{|c|}{ Christian } & \multicolumn{2}{|c|}{ Muslim } & \multirow[t]{2}{*}{ Total } & \multirow[t]{2}{*}{ Total } \\
\hline & Male & Female & Male & Female & Male & Female & & \\
\hline Total & 5 & 11 & 1 & 4 & 24 & 68 & 30 & 83 \\
\hline Grand Total & \multicolumn{2}{|c|}{16} & \multicolumn{2}{|c|}{5} & \multicolumn{2}{|c|}{92} & \multicolumn{2}{|c|}{113} \\
\hline Percentage & $31.25 \%$ & $68.75 \%$ & $20 \%$ & $80 \%$ & $26.08 \%$ & $73.91 \%$ & $26.54 \%$ & $73.45 \%$ \\
\hline \multicolumn{9}{|c|}{ Papillary Microcarcinoma(fig.2) } \\
\hline Religion & \multicolumn{2}{|c|}{ Hindu } & \multicolumn{2}{|c|}{ Christian } & \multicolumn{2}{|c|}{ Muslim } & Total & Total \\
\hline Gender & Male & Female & Male & Female & Male & Female & & \\
\hline Total & 2 & 10 & 0 & 1 & 2 & 23 & 4 & 34 \\
\hline Grand Total & \multicolumn{2}{|c|}{12} & \multicolumn{2}{|c|}{1} & \multicolumn{2}{|c|}{25} & \multicolumn{2}{|c|}{38} \\
\hline Percentage & $16.66 \%$ & $83.33 \%$ & 0 & $100 \%$ & $8 \%$ & $92 \%$ & $10.52 \%$ & $89.48 \%$ \\
\hline \multicolumn{9}{|c|}{ Follicular Variant of Papillary Carcinoma (fig.3) } \\
\hline Religion & \multicolumn{2}{|c|}{ Hindu } & \multicolumn{2}{|c|}{ Christian } & \multicolumn{2}{|c|}{ Muslim } & Total & Total \\
\hline Gender & Male & Female & Male & Female & Male & Female & & \\
\hline Total & 1 & 4 & 0 & 1 & 5 & 27 & 6 & 32 \\
\hline Grand Total & \multicolumn{2}{|c|}{5} & \multicolumn{2}{|c|}{1} & \multicolumn{2}{|c|}{32} & \multicolumn{2}{|c|}{38} \\
\hline Percentage & $20 \%$ & $88 \%$ & 0 & $100 \%$ & $15.62 \%$ & $84.37 \%$ & $15.78 \%$ & $84.21 \%$ \\
\hline \multicolumn{9}{|c|}{ Hurthle Cell Variant of Papillary Carcinoma(fig.4) } \\
\hline Religion & & & & & & & Male & Female \\
\hline Gender & Male & Female & Male & Female & Male & Female & & \\
\hline Total & 1 & 3 & 0 & 0 & 0 & 5 & 1 & 8 \\
\hline Grand Total & & & & & & & & \\
\hline Percentage & $44.44 \%$ & $0 \%$ & 0 & $0 \%$ & $0 \%$ & $55.56 \%$ & $11 \%$ & $89 \%$ \\
\hline Tall Cell Variant & Carcinc & (fig.5) & & & & & & \\
\hline Religion & & & & & & & Total & Total \\
\hline Gender & Male & Female & Male & Female & Male & Female & & \\
\hline Total & 0 & 0 & 0 & 0 & 0 & 1 & 0 & 1 \\
\hline Grand Total & & & & & & & & \\
\hline Percentage & $0 \%$ & $0 \%$ & 0 & $0 \%$ & $0 \%$ & $100 \%$ & $0 \%$ & $100 \%$ \\
\hline
\end{tabular}

\section{Hyalinizing trabecular variant of Papillary Carcinoma}

\begin{tabular}{|c|c|c|c|c|c|c|c|c|}
\hline \multirow{2}{*}{$\begin{array}{c}\text { Religion } \\
\text { Gender }\end{array}$} & \multicolumn{2}{|c|}{ Hindu } & \multicolumn{2}{|c|}{ Christian } & \multicolumn{2}{|c|}{ Muslim } & \multirow[t]{2}{*}{ Total } & \multirow[t]{2}{*}{ Total } \\
\hline & Male & Female & Male & Female & Male & Female & & \\
\hline Total & 0 & 0 & 0 & 0 & 0 & 1 & 0 & 1 \\
\hline Grand Total & \multicolumn{2}{|c|}{0} & \multicolumn{2}{|c|}{0} & \multicolumn{2}{|c|}{1} & \multicolumn{2}{|c|}{1} \\
\hline Percentage & $0 \%$ & $0 \%$ & 0 & $0 \%$ & $0 \%$ & $100 \%$ & $0 \%$ & $100 \%$ \\
\hline
\end{tabular}

Encapsulated follicular variant of Papillary Carcinoma (Lindsay Tumour; fig. 6)

\begin{tabular}{|c|c|c|c|c|c|c|c|c|}
\hline \multirow{2}{*}{$\begin{array}{c}\text { Religion } \\
\text { Gender }\end{array}$} & \multicolumn{2}{|c|}{ Hindu } & \multicolumn{2}{|c|}{ Christian } & \multicolumn{2}{|c|}{ Muslim } & \multirow[t]{2}{*}{ Total } & \multirow[t]{2}{*}{ Tota } \\
\hline & Male & Female & Male & Female & Male & Female & & \\
\hline Total & 1 & 1 & 0 & 0 & 1 & 5 & 2 & 6 \\
\hline Grand Total & \multicolumn{2}{|c|}{2} & \multicolumn{2}{|c|}{0} & \multicolumn{2}{|c|}{6} & \multicolumn{2}{|c|}{8} \\
\hline Percentage & $50 \%$ & $50 \%$ & 0 & $0 \%$ & $16.6 \%$ & $83.3 \% \%$ & $25 \% \%$ & $75 \%$ \\
\hline
\end{tabular}


Table 3: Comparison of Gender distribution of total thyroid carcinomas

\begin{tabular}{lcccc}
\hline Authors & Prades et al10 & Lumachi et al11 & Chehrei et al12 & Present study \\
\hline Male & $18 \%$ & $22.4 \%$ & $16.4 \%$ & $19.32 \%$ \\
\hline Female & $82.18 \%$ & $77.6 \%$ & $83.6 \%$ & $80.68 \%$
\end{tabular}

Table 4: Comparison of age range and mean age of total thyroid carcinomas

\begin{tabular}{lcccc}
\hline & Huber et al & Lumachi et al & Cherit et al & Present study \\
\hline Age range & $19-84 \mathrm{yrs}$ & $18-76 \mathrm{yrs}$ & $21-76 \mathrm{yrs}$ & $10-85 \mathrm{yrs}$ \\
\hline Mean age & $44 \mathrm{yrs}$ & $43 \mathrm{yrs}$ & $43.8 \mathrm{yrs}$ & $34.5 \mathrm{yrs}$
\end{tabular}

carcinoma - 38cases ( $18.27 \%$ ), papillary microcarcinoma -38 cases(18.27\%), Hurthle cell variant- 9 cases $(4.33 \%)$, Lindsay tumour was -8 cases $(3.8 \%)$, tall cell and hyalinizing trabecualar variant constituted one case each $(0.48 \%)$.

Classical PCT was the commonest variant encountered. Muslims were seen to be more affected among the religious groups (162 cases, 77.88\%). Muslim men were commonly affected when compared to men of other religious groups [Muslims- (32 cases) 15.38\%, Hindus-( 10 cases ) 4.80\%, Christians-(1 case,0.48\%)(table2)]. In general, Muslim females and Muslim males were more affected in all variants of papillary carcinoma thyroid in all religious groups whereas Christians (12.01\%) were the least affected group (Table 2).

\section{DISCUSSION}

In this study we are correlating epidemiological and histomorphological data so as to assess the major cause hypothesis for thyroid cancers, focusing more on papillary carcinoma and its variants, comparing it with each other and with other thyroid carcinomas and also correlating with gender, life style and religion. Most of the previous studies however have combined only any two of the three aspects.

Of the total 295 thyroid malignancies in our study, 57 patients were males and 238 were females. Our study showed female preponderance which was comparable to the other studies in literature 13 (Table 3).

It is a well-known fact that thyroid cancer occurs 3 times more in virtually all geographic regions in females than males. The reasons however are not clear. Several studies have shown evidence that female sex hormones play a role in the etiology of thyroid cancers. Pregnancy and hormonal treatment have also been associated with thyroid cancers among women. The hormone-related factors probably act as promoters of tumor growth. ${ }^{14-16}$ In our study too, the female predominance was grossly evident in the incidence of total thyroid cancers as well as in the incidence of PCT category.

The incidence of PCT among females was 80.28\% (167 cases) and among males was only $20.7 \%$ (43 cases). This was in concordance with all the studies in literature; that is papillary carcinoma thyroid is more common among females.

Different literature has stated that there is a highest incidence of papillary carcinoma in women which has been attributed to sex hormones causing carcinogenesis. Literature has shown that early menarche, young parous women with recent pregnancy, all have an increased risk of PCT16. This could be a reason of increased incidence of papillary carcinomas in females our region, as almost all of the women were young and multiparous.

Age range of our study was 10-85yrs with mean age of 34.5 yrs, which is low compared to the other studies in literature. This highlighted the high incidence of thyroid malignancies in younger age group in our study (Table 4).

Thyroid cancer can occur at any age ,but the risk peaks earlier for women $\left(3^{\text {rd }}\right.$ and $6^{\text {th }}$ decades $)$ than men ( $7^{\text {th }}$ and $8^{\text {th }}$ decades). ${ }^{17}$ In our study the mean age affected was 37.2 yrs for females and 38. 9 yrs for males. So in our population of males, the incidence of thyroid cancer was much earlier.

Iodine has an essential role in production and regulation of thyroid hormones. Both iodine deficiency and excess have been considered risk factors of thyroid cancer. Chronic hyper secretion of Thyroid stimulating hormone (TSH) leads to thyroid follicular cell hyperplasia and hypertrophy and this is thought to increase the risk of neoplastic transformation. Long term intake of excessive amounts of iodine can also affect the functioning of the thyroid gland and this can lead to elevated hormone levels. ${ }^{18-24}$

It has also been suggested that deficient iodine intake increase the risk of follicular type and excesses intakes increases the risk of papillary thyroid cancer (world cancer research fund, 1997). Fish, particularly salt water fish, salted dry fish and shell fish is the best natural source of iodine and also most diet like bread, dairy products and iodized table salt are the main source of this mineral. Several studies have pointed out that consumption of processed fish, products such as cheese, butter, cruciferous and pickled vegetables were also associated with excessive consumption of iodine. One author even commented that chicken consumption also 


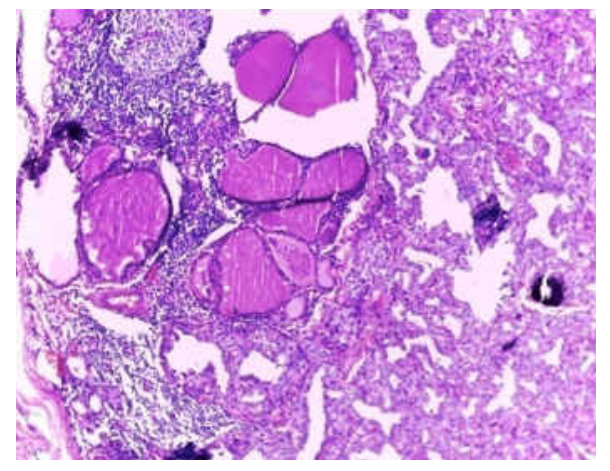

Figure 1: Hashimotos thyroiditis with papillary carcinoma (HE Stain, X100).

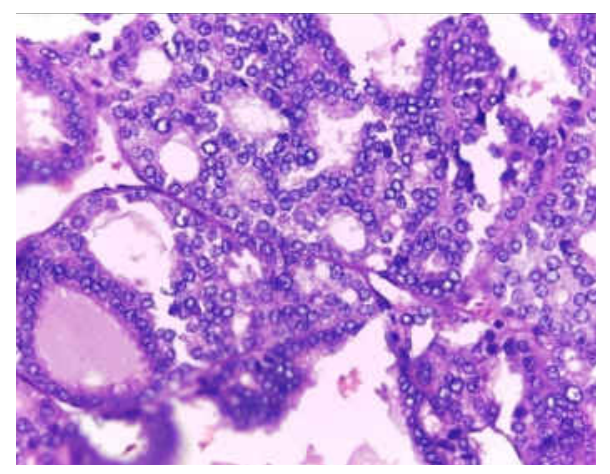

Figure 3: Follicular variant of papillary carcinoma (HE Stain, X400).

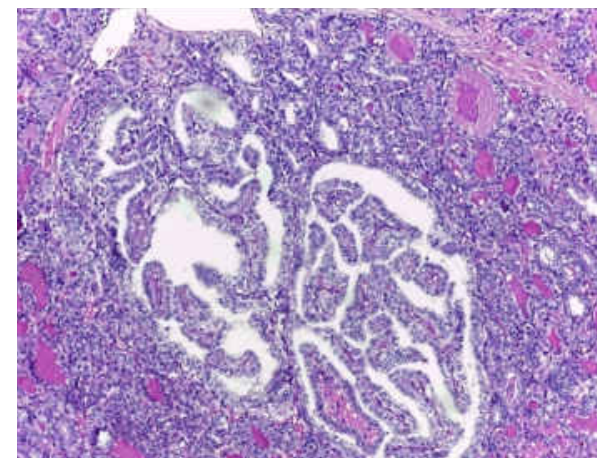

Figure 2: Papillary microcarcinoma of thyroid (HE Stain, X100).

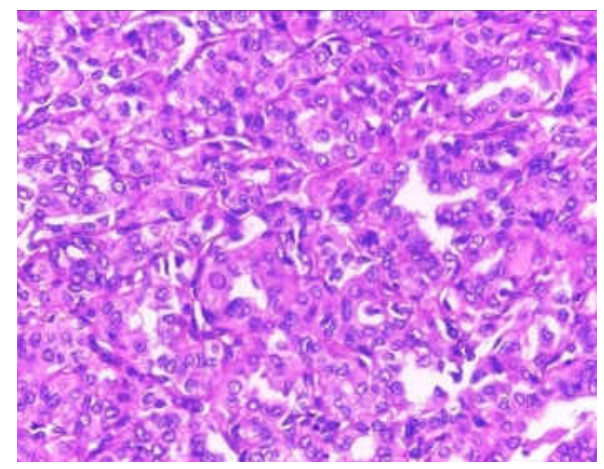

Figure 4: Hurthle cell variant of papillary carcinoma (HE Stain, X400). could be the cause of thyroid carcinoma. ${ }^{18-24}$

South Malabar region in Kerala, India, is located along the Arabian coast; because of its coastal location, fish has always been an important component of the local diet. This could be one of the reasons for the increased incidence of PCT seen in our study.

In addition to iodine itself, dietary factors that interfere with iodine organification and thyroid hormone synthesis, such as cruciferous vegetables could also increase thyroid cancer risk. Frequent contamination of nitrate in drinking water is seen in areas of agriculture and it is found that there are high levels of nitrates in some vegetables and processed food. A high average nitrate level in water supplies is associated with an increased risk of thyroid cancers. ${ }^{25-28}$ Our area, being an agricultural one, there is a high chance of pesticides pollution and water pollution. Along with that we have an increased Middle East influence which leads to increased consumption of processed foods; all these factors might eventually be the cause of increased incidence of PCT in our region.

We found that the incidence of PCT was around $77.9 \%$ in Muslims, $18.6 \%$ in Hindus and 3.52\% in Christians, however, saying that PCT is more common among the Islamic population is not relevant as the area under study was a Muslim predominant one.
In our study we found there was 23 cases (11\%) of Hashimoto/lymphocytic thyroiditis along with PCT. All the cases were seen in females and all had high TSH levels. Attempts have been made to correlate autoimmune thyoiditis and TSH levels. Increasing TSH levels because of the autoimmune process, in turn produces proinflammatory cytokines and oxidative stress. This might trigger thyroid tumorgenesis. Literature has proved that PCT is frequent in patients with autoimmune thyroiditis and is directly related to serum TSH value. ${ }^{28-31}$ Our study was comparable to other studies in literature.

Exposure to ionizing radiation is a well-documented risk factor for cancer. The thyroid may be irradiated more than other tissues because of its position in the body and its ability to concentrate iodine. The thyroid gland is very sensitive at a young age. Children exposed to radiation frequently develop PCT. A recent analysis indicated that thyroid cancer risk and children exposed to head and neck radiation is inversely correlated to the age, decreasing to a statistically insignificant level by age 15 . Recent report indicates that dental and medicals $x$ rays may increase thyroid cancer risk also in adults. One third of all CT scans are performed in the head and neck, where the thyroid is exposed to radiation. ${ }^{28,32-35}$

Numerous histopathological variants have been described in literature and their different behaviors are characterized. Various studies have shown classical papillary carcinoma 


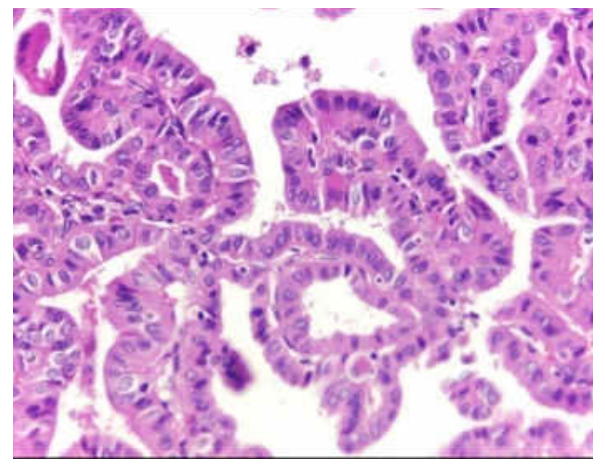

Figure 5: Tall cell variant of papillary carcinoma (HE Stain, X400).

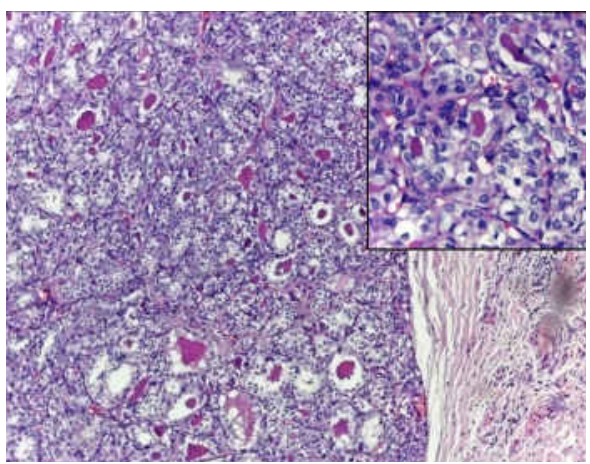

Figure 6: Lindsay tumour (HE Stain, X100). Inset showing high power view of Lindsay tumour. to be the most common variant, followed by papillary microcarcinoma and follicular variant of papillary carcinoma, in decreasing order. ${ }^{1,36}$ In our study too, classical papillary carcinoma was the commonest followed by equal numbers of papillary microcarcinoma and follicular variant of papillary carcinoma. The tall cell and Hyalinizing trabecualr variants was the least encountered types in our study.

Papillary carcinoma thyroid is the most common malignancy among thyroid cancers. It has an excellent clinical behavior in spite of the presence of lymph node metastasis. Our study of papillary thyroid carcinomas in South Malabar region, Kerala, India shows that there is a high incidence of thyroid carcinomas and this could be attributed to various factors like high intake of iodine along coastal region, excessive salt iodization, increased consumption of processed food and fish, influence of female sex hormones, increased incidence of autoimmune thyroiditis and exposure to radiation. Our study also showed increased incidence of PCT in females and men and women of Islamic faith.Classical PCT was the commonest variant encountered in our study.

\section{CONCLUSION}

Papillary carcinoma thyroid is the most common malignancy among thyroid cancers. It has an excellent clinical behavior in spite of the presence of lymph node metastasis. Our study of papillary thyroid carcinomas in South Malabar region, Kerala, India shows that there is a high incidence of thyroid carcinomas and this could be attributed to various factors like high intake of iodine along coastal region, excessive salt iodization, increased consumption of processed food and fish, influence of female sex hormones, increased incidence of autoimmune thyroiditis and exposure to radiation. Our study also showed increased incidence of PCT in females and men and women of Islamic faith.Classical PCT was the commonest variant encountered in our study.

\section{Acknowledgment}

We sincerely thank all the surgeons and pathologists of MES medical college, Perithalmanna, Kerala, India.

\section{REFERENCES}

1. Anirban Mitra, Abul K.Abbas.The endocrine system -thyroid gland, In Kumar Vinay, Abul K. Abbas, Nelson Fausto, Stanley L. Robbins, and Ramzi S. Cotran editors. Robbins and Cotran Pathologic Basis of Disease. Philadelphia: Elsevier Saunders, 2005. pp1155-1226.

2. Cooper DS, Doherty GM, Haugen BR, Kloos RT, Lee SL, Mandel SJ, et al. American Thyroid Association Guidelines Taskforce on Thyroid Nodules and Differentiated Thyroid Cancer, Revised American Thyroid Association management guidelines for patients with thyroid nodules and differentiated thyroid cancer. Thyroid 2009; 19:1167-1214. Crossref

3. Jemal A, Siegel R, Xu J, Ward E.cancer statistics,2010 CA Cancer J Clin. 2010;60:277-300. Crossref

4. Andrii Dinets, Mykola Hulchiy, Anastasios Sofiadis et al. Clinical, genetic, and immunohistochemical characterization of 70 Ukrainian adult cases with post-Chornobyl papillary thyroid carcinoma. Eur J Endocrinol.2012;166:1049-60. Crossref

5. Al-Brahim N, Asa SL. Papillary thyroid carcinoma: an overview. Arch Pathol Lab Med 2006;130:1057-62. Crossref

6. Gangadharan P, Nair MK, Pradeep VM. Thyroid Cancer in Kerala. In: Shah AH, Samuel AM, Rao RS, editors. Thyroid Cancer- An Indian Perspective. Mumbai: Quest Publications;1999.pp17-32.

7. Sakoda LC and Horn-Ross PL. Reproductive and menustral history and papillary thyroid cancer risk: The San Francisco Bay Area thyroid cancer study. Cancer Epidemiology Biomarkers and Prevention 2002;11:51-7. Crossref

8. Haselkorn T, Stewart SL and Horn-Ross PL. Why are thyroid cancer rates so high in South East Asian women living in the United States? The Bay Area Thyroid cancer Study Cancer Epidemiology Biomarkers and Prevention 2003;12:144-50. Crossref

9. Ronald A. Delellis, E.D Williams. Thyroid and Parathyroid tumours. In Ronald A. Delellis, Richardo V. Lloyd, Philips U. Heitz, Charis Eng. Tumours of Endocrine organs (WHO).IARC Press Lyon France,2004. 
10. Prades JM, Querat C, Dumollard JM et al. Thyroid nodule surgery: predictive diagnostic value of fine-needle aspiration cytology and frozen section. Eur Ann Otorhinolaryngol Head Neck Dis 2013;130:195-9. Crossref

11. Lumachi F, Borsato S, Tregnaghi A, et al. FNA cytology and frozen section examination in patients with follicular lesions of the thyroid gland. Anticancer Res. 2009;29:5255-7. Crossref

12. Chehrei A, Ahmadinejad M, Tabatabaee SA, Hashemi SM, kianinia M, Fateh S, Sanei MH. "Touch imprint and crash preparation intra operative cytology versus frozen section in thyroid nodule." J Res Med Sci 2012;17:475-80. Crossref

13. J. Rosai, "Thyroid gland," in Rosai and Ackerman's Surgical Pathology, J. Rosai and L. Ackerman, Eds., 9th edition. Mosby, Edinburgh, Scotland, 2004. pp. 515-594,

14. Rossing MA, Voigt L F, Wicklund KG, Daling JR. Reproductive factors and risk of papillary thyroid cancer in women. American journal of epidemiology. 2000;151:765-72. Crossref

15. Haselkorn T, Stewart SL, Horn-Ross PL. Why are thyroid cancer rates so high in southeast asian women living in the United States? The bay area thyroid cancer study. Cancer Epidemiology Biomarkers \& Prevention 2003;12:144-50. Crossref

16. Sakoda LC, Horn-Ross, PL. Reproductive and Menstrual History and Papillary Thyroid Cancer Risk The San Francisco Bay Area Thyroid Cancer Study. Cancer Epidemiology Biomarkers \& Prevention 2002;11:51-7. Crossref

17. Crossref

18. Glade MJ. Food, nutrition, and the prevention of cancer: a global perspective (American Institute for Cancer Research/World Cancer Research Fund, American Institute for Cancer Research, 1997) Nutrition.1999;15(6):523-6. Crossref

19. Ron E, Kleinerman RA, Boice JD, LiVolsi VA, Flannery JT, Fraumeni JF. A population-based case-control study of thyroid cancer. Journal of the National Cancer Institute 1987;79:1-12. Crossref

20. Ron E. Thyroid cancer. In: Schottenfeld D, Fraumeni JF, Jr, eds. Cancer Epidemiology and Prevention. Oxford University Press, New York, 1996, pp. 1000-1021.

21. Bosetti C, Kolonel L, Negri E et al. A pooled analysis of case-control studies of thyroid cancer. VI. Fish and shellfish consumption. Cancer Causes and Control 2001;12:375-82. Crossref

22. Galanti MR, Hansson L, Bergström R et al. Diet and the risk of papillary and follicular thyroid carcinoma: a population-based case-control study in Sweden and Norway. Cancer Causes Control 1997;8:205-14. Crossref

23. Glattre E, Haldorsen T, Berg JP, Stensvold I, Solvoll K. Norwegian case-control study testing the hypothesis that seafood increases the risk of thyroid cancer. Cancer Causes \& Control 1993;4:11-6. Crossref

24. Memon A, Varghese A, Suresh A. Benign thyroid disease and dietary factors in thyroid cancer: a case-control study in Kuwait. Br J Cancer 2002;86:1745-50. Crossref

25. Peterson E, De P, Nuttall R. BMI, diet and female reproductive factors as risks for thyroid cancer: a systematic review. PLoS One. 2012;7:e29177. Crossref

26. Kilfoy BA, Zhang Y, Park Y et al. Dietary nitrate and nitrite and the risk of thyroid cancer in the NIH $\square$ AARP Diet and Health Study. International Journal of Cancer 2011;129:160-72. Crossref

27. Ward MH, Kilfoy BA, Weyer PJ, Anderson KE, Folsom AR, Cerhan JR. Nitrate intake and the risk of thyroid cancer and thyroid disease. Epidemiology 2010;21:389-95. Crossref

28. Pellegriti G, Frasca F, Regalbuto C, Squatrito S, Vigneri R. Worldwide increasing incidence of thyroid cancer: update on epidemiology and risk factors. J Cancer Epidemiol. 2013;2013:965212. Crossref

29. Fiore E, Rago T, Provenzale MA et al. L-thyroxine-treated patients with nodular goiter have lower serum TSH and lower frequency of papillary thyroid cancer: results of a cross-sectional study on 27914 patients. Endocrine-related cancer, 2010;17:231-9. Crossref

30. Repplinger D, Bargren A, Zhang YW, Adler JT, Haymart M, Chen H: Is Hashimoto's thyroiditis a risk factor for papillary thyroid cancer? J Surg Res 2007;150:49-52. Crossref

31. Khatami M. Inflammation, aging, and cancer: tumoricidal versus tumorigenesis of immunity. Cell biochemistry and biophysics 2009;55:55-79. Crossref

32. Mettler FA, Bhargavan M, Thomadsen BR et al.Nuclear medicine exposure in the United States, 2005-2007: preliminary results. In Seminars in nuclear medicine. WB Saunders. 2008;38:384-91.

33. Mettler Jr FA, Wiest PW, Locken J A, Kelsey C A. CT scanning: patterns of use and dose. J Radiol Prot. 2000;20:353-9. Crossref

34. Linton OW, Mettler Jr FA. (2003). National conference on dose reduction in $\mathrm{CT}$, with an emphasis on pediatric patients. American Journal of Roentgenology 2003;181:321-9. Crossref

35. Memon A, Godward S, Williams D, Siddique I, Al-Saleh K. Dental $\mathrm{X}$-rays and the risk of thyroid cancer: a case-control study. Acta Oncologica 2010;49:447-53. Crossref

36. Gonzalez-Gonzalez R, Bologna-Molina R, Carreon-Burciaga RG, Gómezpalacio-Gastelum M, Molina-Frechero, N, Salazar-Rodríguez S. Papillary thyroid carcinoma: differential diagnosis and prognostic values of its different variants: review of the literature. ISRN oncology, 2011Article ID 915925, 9 pages. Crossref 